\title{
Productivity and Soil Health of Potato (Solanum tuberosum L.) Field as Influenced by Organic Manures, Inorganic Fertilizers and Biofertilizers under High Altitudes of Eastern Himalayas
}

\author{
Manoj Kumar (Corresponding author) \\ Research Fellow, Division of Natural Resource Management (NRM) \\ Indian Council of Agricultural Research (ICAR) for NEH Region Umroi \\ Road, Barapani Umiam-793103, Meghalaya, India \\ Tel: 91-364-257-0306 E-mail: mkumar_cprs@yahoo.co.in
}

L.K. Baishaya

Farm Manager, ICAR Research Complex for NEH Region, Nagaland centre, Jharnapani, Nagaland, India

D.C. Ghosh

Proferssor of Agronomy, Department of ASEPAN, Visva-Bharati University

PSB, Santiniketan, West Bengal, India

V.K. Gupta

Senior Scientist (Vegetable Sciences), Central Potato Research Institute

Campus Modipuram, Meerut, U.P. India

S.K. Dubey

Senior Scientist (Agricultual Extension), Indian Agricultural Research Institute

Pusa Capmus New Delhi-12, India

Anup Das

Senior Scientist (Agronomy), Division of Natural Resource Management (NRM)

ICAR Research Complex for NEH Region, Umroi Road, Umiam-793103, Meghalaya, India

D. P. Patel

Senior Scientist (Plant Physiology), Division of Natural Resource Management (NRM)

ICAR Research Complex for NEH Region, Umroi Road, Umiam-793103, Meghalaya, India

Received: December 19, $2011 \quad$ Accepted: January 13, $2011 \quad$ Online Published: April 1, 2012

doi:10.5539/jas.v4n5p223

URL: http://dx.doi.org/10.5539/jas.v4n5p223

\begin{abstract}
Field experiments were conducted in three consecutive summer seasons of 2005 to 2007 to study the effect of integrated nutrient management on soil health and productivity of potato (Solanum tuberosum L.) under rainfed condition. The experiment was laid out in a split plot design with eight nutrient management practices (combinations of organic manures viz, farm yard manure (FYM), poultry manure (PM), vermicompost (VC) and
\end{abstract}


inorganic fertilizers in main plots and seed tuber treatment with three biofertilizers (Azotobactor, phosphorus solubilizing bacteria (PSB) and Azotobactor + PSB) in sub plots. The results showed that $50 \%$ of the recommended dose of NPK through inorganic $+50 \%$ recommended dose of nitrogen (RDN) through organic manures (FYM, PM or VC) or 100\% recommended dose of NPK through inorganic fertilizers alone favorably influenced the tuber yield, nutrient uptake, soil fertility and paid higher returns compared to other treatments. Seed treatment with Azotobactor + PSB proved better in tuber yield, nutrient uptake and recorded higher returns as compared to sole treatment of either Azotobactor or PSB. Three years pooled result revealed that integrated application of $50 \%$ of recommended NPK through inorganic and $50 \%$ RDN through PM recorded significantly highest tuber yield $(22.73 \mathrm{t} / \mathrm{ha})$ closely followed by $100 \%$ recommended NPK through inorganic $(22.20 \mathrm{t} / \mathrm{ha})$ which were $228 \%$ and $223 \%$ respectively, higher than control. Integrated application of inorganic and organic fertilizers and seed treatment with Azotobactor + PSB biofertilizers improved tuber yield, nutrient uptake, and gave higher return as compared to other treatment combinations. Total organic carbon (TOC), soil microbial biomass carbon (SMBC), available $\mathrm{N}, \mathrm{P}$, and $\mathrm{K}$ status of the soil after 3 years were maximum when $50 \%$ recommended dose of NPK were applied through inorganic and remaining $50 \%$ RDN through PM.

Keywords: Organic manures, Inorganic fertilizer, Biofertilizer, Potato tuber yield, Economics, Soil health, Hill Agriculture

\section{Introduction}

Potato is an economical food and it provides a source of low cost energy to the human diet. Potato is the rich source of starch, vitamin C and B and minerals. It contains about $20.6 \%$ carbohydrates, $2.1 \%$ protein, $0.3 \%$ fat, $1.1 \%$ crude fibre and $0.9 \%$ ash. It also contains a good amount of essential amino acids like leucine, tryptophane and isolucine (Khurana and Naik, 2003). Potatoes are cultivated over an area of 19.3 million hectares in 150 countries of the world with a total production of 308 million tones. In India, potato is cultivated in an area of about 1.34 million hectares with a total production of about 24.7 million tones. It is cultivated on a large scale in Uttar Pradesh, West Bengal, Bihar and Punjab. The potato productivity is very low in North Eastern hill (NEH) region of India (8.64 t/ha) except in Tripura $(17.3 \mathrm{t} / \mathrm{ha})$ due to poor management practices (Burman et al., 2007).

There is a need for launching a National movement to safe guard soil health and improve soil fertility (Swaminathan, 2004) of potato fields. As no single source is capable of supplying the required amount of plant nutrients, integrated use of all sources of plant nutrients is a must to supply balanced nutrition to the crops (Arora, 2008). The integrated nutrient management (INM) systems envisage use of organic manures along with chemical fertilizers. A number of diverse organic sources are available for use in agriculture in the NEH region due to its favourable agroclimatic conditions. These sources can reduce the mining of soil nutrient and improve overall soil productivity in terms of improved physico-chemical and biological conditions of the soil. The soils of the NEH region are acidic to strongly acidic due to leaching of bases owing to high rainfall $(>2000 \mathrm{~mm})$. The law availability of $\mathrm{P}$ due to fixation as $\mathrm{Fe} / \mathrm{Al}$ - complex is the major problem of crop production in the region. Biofertilizers like phosphorus solubilizing bacteria (PSB) /Azotobactor may be useful for improving P and N nutrition in potato. The beneficial effects of organic manures are manifested through increase in soil organic matter and humus over the period. Soil organic matter and humus acts in several ways; it serves as slow release source of plant nutrients to the crops and increases water holding capacity to maintain the water regime of the soil and acts as a buffer against change in soil pH (Upadhayay and Singh, 2003).

Fertilizer requirement of potato is very high as compared to cereal crops. It responds well to applied fertilizers and gives good yield per unit area and time. Fertilizer being a costly input, PSB could supplement the nutrient requirement of the potato crop especially the phosphorus and thereby boosting the yield (Praharaj et al., 2002). Integrated nutrient management (INM) involving combination of organic manure and fertilizers is an essential tool for balanced fertilization and sustainability of crop production on long term basis (Hegde and Dwivedi, 1993). Application of organic manures in conjunction with fertilizers improves physical, chemical and biological properties of the soil besides improving fertilizer use efficiency and crop yield. Asiegbu and Oikeh (1995) found that $\mathrm{N}, \mathrm{P}$ and $\mathrm{K}$ fertilizers were more efficient than the organic manures in supplying $\mathrm{N}, \mathrm{P}$ and $\mathrm{K}$ to the growing plant at least in the short run, while the organic manure had an advantage to supply other macro- and micro-nutrients not contained in N, P and $\mathrm{K}$ fertilizers. But no such systematic study was made in acid soil of $\mathrm{NEH}$ region of India i.e, the Indian Eastern Himalayas. Keeping this in mind a field study was undertaken to investigate the effect of integrated use of organic manures and inorganic fertilizers along with biofertilizers on productivity of potato and its economics in the hills of Meghalaya, the Indian Eastern Himalayas. 


\section{Materials and Methods}

\subsection{Experimental Site}

The experiment was carried out during the summer seasons (March to July) of 2005, 2006 and 2007 at Central Potato Research Station (ICAR), upper Shillong, Meghalaya, India. The maximum temperature ranged from 20.11 to $26.34{ }^{\circ} \mathrm{C}$ in $2005,20.06$ to $25.66{ }^{\circ} \mathrm{C}$ in 2006 and 16.83 to $26.99{ }^{\circ} \mathrm{C}$. The minimum temperature varied from 9.71 to $18.16{ }^{\circ} \mathrm{C}$ in $2005,9.96$ to $21.29{ }^{\circ} \mathrm{C}$ in 2006 and 7.43 to $18.44{ }^{\circ} \mathrm{C}$ in 2007 . The temperature began to rise from the month of March and reaches maximum in July during all three years. The distribution pattern of rainfall is presented in the fig 1.The experimental soil was acidic in reaction ( $\mathrm{pH}$ 5.3), high in organic carbon $(1.23 \%)$, low in available $\mathrm{P}(13.35 \mathrm{~kg} / \mathrm{ha})$, medium in $\mathrm{N}(178.50 \mathrm{~kg} / \mathrm{ha})$, and potassium $(195.10 \mathrm{~kg} / \mathrm{ha})$.

\subsection{Experimental Details and Crop Culture}

The field experiment was laid out in a split plot design with eight nutrient management options in main-plot and three seed (tuber) treatment with biofertilizers in sub-plot and replicated thrice. Nutrient management practices were $\mathrm{F}_{1}=$ Control, $\mathrm{F}_{2}=100 \%$ recommended dose of Nitrogen $(\mathrm{RDN})$ through $\mathrm{FYM}, \mathrm{F}_{3}=100 \% \mathrm{RDN}$ through poultry manure $(\mathrm{PM}), \mathrm{F}_{4}=100 \% \mathrm{RDN}$ through vermicompost $(\mathrm{VC}), \mathrm{F}_{5}=50 \%$ recommended dose of NPK through inorganic fertilizers $+50 \% \mathrm{RDN}$ through $\mathrm{FYM}, \mathrm{F}_{6}=50 \%$ recommended dose of NPK through inorganic fertilizers $+50 \%$ RDN through poultry manure $(\mathrm{PM}), \mathrm{F}_{7}=50 \%$ recommended dose of NPK through inorganic fertilizers $+50 \%$ RDN through vermicompost $(\mathrm{VC}), \mathrm{F}_{8}=100 \%$ recommended dose of NPK (RDNPK) through inorganic fertilizers. The Biofertilizers seed treatments were $\mathrm{T}_{1}=$ Azotobactor $\mathrm{T}_{2}=$ Phosphate solubilizing bacteria (PSB), $\mathrm{T}_{3}=$ Azotobactor $+\mathrm{PSB}$. The hybrid potato variety 'Kufri Giriraj' tubers were planted in second week of March and harvested in first week of July in all the three years. The average duration of the crop was 120 days. The recommend dose of nitrogen was $120 \mathrm{~kg} \mathrm{~N} / \mathrm{ha}$. FYM $23.0 \mathrm{t} / \mathrm{ha}, \mathrm{PM} 8.0 \mathrm{t} / \mathrm{ha}$ and VC $10.0 \mathrm{t} / \mathrm{ha}$ were used to supply $100 \% \mathrm{RDN}(120 \mathrm{~kg} \mathrm{~N} / \mathrm{ha}$ ) to the potato crop. The nutrient composition of organic manures is presented in Table 1.Well decomposed FYM, PM and VC as per treatment were applied 15 days before final land preparation. Half dose of $\mathrm{N}$ and full dose of $\mathrm{P}$ and $\mathrm{K}$ in the form of urea, single super phosphate, and muriate of potash, respectively were applied as per treatment as basal dose before planting. The remaining half dose of $\mathrm{N}$ was applied at earthling up (35 days after planting). For seed tuber treatment, half $\mathrm{kg}$ each of Azotobactor and PSB biofertilizers were dissolved in 40 litres of water separately. A slurry was prepared by boiling $2 \mathrm{~kg}$ jaggary in one litre of water. After cooling, it was added to each solution of biofertilizers. In case of combined application of both the biofertilizers, $250 \mathrm{~g}$ of each biofertilizer were dissolved in 40 litres of water and added to the jaggary solution. In this way three solutions of biofertilizers (solution of Azotobactor, PSB and Azotobactor + PSB) were prepared. Potato (cv. kufri giriraj) tubers were dipped in the biofertilizer solution for 30 minutes as per treatment and shade dried before sowing. The tubers were planted at $20 \mathrm{~cm}$ apart in the furrows of $60 \mathrm{~cm}$ distance and covered immediately after planting. The earthing up was done at 35 days after planting along with weeding to facilitate the development of tubers at the stolon tips. During earthing up the remaining nitrogen dose was side dressed and mixed thoroughly with the soil. Other than late blight there were no major incidence of insect pest. For controlling of late blight two spray with $0.2 \%$ mancozeb and one spray of Ridomil MZ (metalaxyl + mancozeb) $0.25 \%$ were sprayed. The crop was harvested manually at maturity in bright sunny days. All the tubers were dried and graded in shade and their weight and number were recorded as grades A (50g and above), B (30-50 g) and C (less than $30 \mathrm{~g}$ ). Then tuber yield of different plots were estimated and converted into tonnes/hectare.

\subsection{Plant and Soil Sampling}

The tubers of each plot were separated into A, B and C grades and their weights were recorded from each plot and converted into $t / h$. Total yield was recorded by addition of grade A, B and C. The post harvest soil samples were collected from 0 to $20 \mathrm{~cm}$ horizon for analyzing the available nutrient status.

\subsection{Chemicals Analysis}

Percent nutrient content of potatoes and nutrient uptake was determined at harvest following standard procedure. Soil samples were collected $(0-20 \mathrm{~cm}$ depth) after harvest of crop each year and analyzed for various physico-chemical and biological parameters following standard procedures. The $\mathrm{pH}$ was determined in a 1:2.5 soil: water suspension (Jackson, 1973), organic carbon (OC) determined following Walkey and Black (1934), available N by alkaline Potassium Permanganate method (Subbiah and Asajia, 1956), available P by Bray's method (Bray and Kurtz, 1945) and available K by Ammonium Acetate Extraction method (Jackson, 1973). The SMBC was determined by the ethanol-free chloroform fumigation extraction method (Vance et al. 1987) using $K_{c}$ value of 0.45 (Jenkinson and Ladd, 1981). 


\subsection{Economics Analysis}

The cost of organic manures and chemical fertilizers, other inputs (labour, seeds, pescticides etc) and outputs (Tuber) were estimated as per prevailing market price. The gross return, net return and return per dollar invested in different nutrient management systems were assessed by computing the cost of the inputs and price of the produce/output.

\subsection{Statistical Analysis}

The analysis of variance methods (Panse and Sukhatme, 1978) was followed to statistically analyze the various data. The significance of different sources of variations was tested by Error mean square of Fisher Snedecor's 'F' test at probability level $(P=0.05)$. In the summery tables of the results, the standard error of mean $(\mathrm{Sem} \pm)$, the value of critical difference (CD) and coefficient of variation (CV) to compare the difference between the means have been provided.

\section{Results and Discussion}

\subsection{Grade Wise Tuber Yield}

Various nutrient management practices had significant effect on grade wise tuber yield of potato during all the three years. In general there was maximum production of grade ' $\mathrm{B}$ ' tubers followed by grade ' $\mathrm{A}$ ' and ' $\mathrm{C}$ '. Integrated use of $50 \%$ recommended dose of NPK (50\% RDNPK) through inorganic fertilizers and remaining $50 \%$ RDN through organic sources (FYM, PM or VC) and application of $100 \%$ RDNPK through inorganic fertilizers recorded higher tuber yield of all grades (grade A, B and C) which were significantly greater than other fertility treatments during all the three years. The highest tuber yield of different grades were obtained with the application of $50 \%$ RDNPK through inorganic fertilizers and remaining 50\% RDN through PM, which were at par with the crop receiving $50 \%$ RDNPK through inorganic fertilizers and remaining $50 \%$ RDN through FYM or VC or $100 \%$ RDNPK through inorganic fertilizers. The results (Table 2) emphasized the need of integrated use of $50 \%$ RDNPK through inorganic fertilizers and remaining 50\% RDN through organic sources (FYM, PM or VC) for producing high tuber yield of different grades under Meghalaya hill region. The results further indicated that supply of $100 \%$ nutrients through only organic manures was not much helpful in recording high production of different grades tubers under this situation. This might be due to slow mineralization of plant nutrients under low temperature condition prevailing in the hilly and mountainous Himalayan region. The favourable effect of integrated nutrient management through both inorganic fertilizers and organic manures on increasing the different grades tuber production was also noticed by Kumar et al. (2008 and 2011) and Das et al., (2009). Use of biofertilizer exerted significant effect on influencing yield of different grades tubers during all the three years of study. Seed treatment with combination of Azotobactor \& PSB recorded the highest tuber yield of different grades which were significantly greater than those of the crop receiving either Azotobactor or PSB only. Interaction effect of nutrient management and biofertilizers was found not significant in influencing the production of different grades tubers during all the three years.

\subsection{Total Tuber Yield}

The results showed (Table 3) significant variation in total tuber yield due to the different nutrient management practices. The highest tuber yield was obtained with the application of $50 \%$ RDNPK through inorganic fertilizers and remaining 50\% RDN through PM, but it was statistically at par with $50 \%$ RDNPK through inorganic fertilizers and remaining 50\% RDN through FYM or VC or $100 \%$ RDNPK through inorganic fertilizers only during all the three years. These yields were significantly superior to sole application of $100 \%$ RDN either through FYM or PM or VC as well as control. Single application of PM, FYM and VC also recorded significantly higher tuber yield than control. There was $128 \%$ increase in tuber yield due to combined application of $50 \%$ RDNPK through inorganic fertilizers and remaining 50\% RDN through PM and $123 \%$ increase with $100 \%$ RDNPK through inorganic fertilizers only over the control. Seed treatment with combination of Azotobactor + PSB recorded significantly higher tuber yield compared to either only Azotobactor or PSB treatment during all the years. Interaction effect of fertility management and biofertilizers on tuber yield of potato was found significant during all the years. The crop receiving $50 \%$ RDNPK through inorganic fertilizers and remaining 50\% RDN through PM along with combined biofertilizers seed treatment ( Azotobactor + PSB) recorded the highest tuber yield that was closely followed by the crop receiving $50 \%$ RDNPK through inorganic fertilizers and remaining 50\% RDN through FYM or VC and 100\% RDNPK through inorganic fertilizers along with Azotobactor or PSB. Supply of $100 \%$ RDNPK through inorganic fertilizers along with biofertilizers exerted relatively lower effect on increasing tuber yield as compared to those of the crop receiving $50 \%$ RDNPK through inorganic fertilizers and remaining 50\% RDN through organic manures. The biofertilizer seed treatments applied without manures and fertilizers showed very poor performance on tuber productivity of potato 
under the study. The results showed that biofertilizer required organic manuring for its early establishment necessary for exerting beneficial effect on tuber productivity. The results corroborate the findings of Kumar et al. (2001) and Raghav and Kamal (2008). Similar results were reported by Kumar et al., (2011).

\subsection{Nutrient (N, $P$ and $K$ ) Uptake}

The highest uptake of N, P and K by tuber and haulm (Table $4 \& 5$ ) were noticed with the application of $50 \%$ RDNPK through inorganic fertilizers and remaining 50\% RDN through PM, but it was statistically at par with those obtained from the crop receiving $50 \%$ RDNPK through inorganic fertilizers and remaining 50\% RDN through VC and $100 \%$ RDNPK through only inorganic fertilizers. The favourable effect of integrated nutrient management through inorganic fertilizers and organic manures on increasing the $\mathrm{N}, \mathrm{P}$ and $\mathrm{K}$ uptake by tubers were also noticed by other researchers (Kumar et al., 2008; Baishya 2009; Das et al., 2009). Biofertilizer treatments also exerted significant effect on $\mathrm{N}, \mathrm{P}$ and $\mathrm{K}$ uptake by tubers during all the three years. Seed treatment with combination of Azotobactor + PSB recorded the highest uptake of N, P and $\mathrm{K}$ by tubers. Interaction effect of fertility management and biofertilizers on uptake of $\mathrm{N}, \mathrm{P}$ and $\mathrm{K}$ by tubers was found significant during all the years. The crop receiving $50 \%$ RDNPK through inorganic fertilizers and remaining $50 \%$ RDN through PM along with Azotobactor + PSB seed treatment recorded the highest N, P and K uptake by tubers. The results are in conformity with the findings of Kumar et al., (2001) and Raghav and Kamal, (2008).

\subsection{Effect of Treatment on Soil Fertility}

The TOC, SMBC and ratio of SMBC to TOC varied significantly among the different nutrient management treatments (Table 6). The TOC varied from 9.13 in control to $14.43 \mathrm{~g} / \mathrm{kg}$ of soil in $100 \%$ FYM (RDN) plots, whereas, the SMBC ranged from 121.5 in control to $197.0 \mathrm{mg} / \mathrm{kg}$ of soil in $100 \% \mathrm{VC}(\mathrm{RDN})$ treated plots. Both TOC and SMBC reduced substantially in control plots (without manure and fertilizer) from their initial values $(12.3 \mathrm{~g} / \mathrm{kg}$ and $145.0 \mathrm{mg} / \mathrm{kg}$ of soil respectively). The ratio of SMBC to TOC increased over its initial value $(11.79 \mathrm{mg} / \mathrm{g}$ ) due to different fertility management treatments except in plots receiving $100 \%$ RDNPK through inorganic fertilizers alone which recorded SMBC to TOC ratio much below the control and initial value. Application of $100 \%$ RDN through organic manures (PM, VC and FYM) exerted maximum benefit in increasing both TOC and SMBC which were markedly higher than those plots receives $50 \%$ RDNPK through inorganic fertilizers and remaining 50\% RDN through organic manures which in turn also significantly increased both TOC and SMBC over the initial value and that of the control plots. Application of organic manures either alone or in combination with inorganic fertilizers was beneficial for improving or maintaining organic carbon pool in soil. The results corroborate the findings of Manna et al., (2006) and Ghosh et al., (2009).

Biofertilizers treatments did not exert significant effect on soil TOC, SMBC and ratio of SMBC/TOC under the study. Interaction effect of nutrient management and biofertilizers on total organic carbon, microbial biomass carbon and ratio of SMBC/TOC were not significant.

\subsection{Available Soil Nutrient Status of the Experimental Soil}

The available N, P and K contents in the soil increased gradually after each year due to the application of recommended dose of nutrients either through inorganic fertilizers or through integrated application of inorganic fertilizers and organic manures. The plots receiving $50 \%$ RDNPK through inorganic fertilizers and remaining $50 \%$ RDN through PM registered the highest available N, P and K status in the soil and it was closely followed by the plots receiving $50 \%$ RDNPK through inorganic fertilizers and remaining $50 \%$ RDN through VC or FYM, but was markedly higher than those of the plots receiving 100\% RDNPK through only inorganic fertilizers during all the three years (Table 7). Application of $100 \%$ RDN through organic manures only (PM, VC and FYM) also significantly enhanced the available N, P and K status of soil over its initial values and those of the control plots. Application of $100 \%$ RDNPK through only inorganic fertilizers also increased the available N, P and $\mathrm{K}$ status in the soil over its initial values. Whereas, the available $\mathrm{N}, \mathrm{P}$ and $\mathrm{K}$ status in the soil decreased gradually over the years in control plots. The results emphasized the need for integrated nutrient management practices through inorganic fertilizers and organic sources (particularly PM or VC) for enhancing the available N, $\mathrm{P}$ and $\mathrm{K}$ contents in soil. Similar favourable effect of integrated nutrient management involving inorganic fertilizers and organic manures on increasing the available $\mathrm{N}, \mathrm{P}$ and $\mathrm{K}$ contents in soil have been noticed by Jayaram et al., (1990), Kumar et al., (2008) and Baishya (2009). Zaman et al., (2011) also reported that FYM (a)30 t/ha along with biofertilizers recorded maximum soil fertility build-up after harvest of the crop. Biofertilizers treatments did not exert significant effect on available N, P and K status of the soil under the study. 


\subsection{Economics}

Both gross return and net return varied markedly among the nutrient management practices. The crop receiving $50 \%$ RDNPK through inorganic fertilizers and remaining 50\% $\mathrm{N}$ through organic sources (FYM, PM or VC) and $100 \%$ RDNPK through inorganic fertilizers paid higher gross and net return than those of the crop at other fertility treatments. The highest gross and net returns were obtained from the crop receiving $50 \%$ RDNPK through inorganic fertilizers and remaining 50\% RDN through PM followed by the crop receiving $50 \%$ RDNPK through inorganic fertilizers and remaining 50\% RDN through VC or FYM or 100\% RDNPK through inorganic fertilizers (Table 8). Application of $100 \%$ RDN through organic manures (FYM, PM or VC) though recorded higher gross and net returns over the control plots, but these treatments were found less effective in increasing both gross and net returns as compared to those of the crop receiving both inorganic fertilizers and organic manures. The crop at control plots paid very low gross and net returns mainly due to low productivity. The return per $\$$ invested followed a trend similar to that of gross and net returns. The crop at $50 \%$ RDNPK through inorganic fertilizers and remaining 50\% RDN through organic sources (FYM, PM or VC) and 100\% RDNPK through inorganic fertilizers paid much higher net return per $\$$ invested (NRP) than those of other fertility treatments. Vermicompost was found less economic due to its high price, reducing the net return per $\$$ invested. Application of $100 \%$ RDN through organic manures paid lesser NRP compared to those of $100 \%$ RDNPK or $50 \%$ RDNPK through inorganic fertilizers $+50 \%$ RDN through organic manures, mainly due to high cost involvement with organic sources alone. The results are in conformity with the findings of Ghosh and Malik, (1999), Das et al., (2006), Kumar et al., (2008) and Baishya, (2009). Seed treatment with Azotobactor + PSB combination recorded higher gross and net returns as compared to those of the crop treated with either Azotobactor or PSB during all the three years (Table 8). The net return per $\mathbf{\$}$ invested did not vary appreciably among the biofertilizer treatments.

\section{Conclusion}

Potato requires adequate nutrition under acid soils of high hills in eastern Indian Himalayas that may be achieved by judicious and balanced use of organic and inorganic sources of nutrients. The application of $50 \%$ recommended dose of NPK (60:60:30) through inorganic fertilizers and remaining 50\% recommended dose of $\mathrm{N}$ (60 kg N/ha) through organic manures like poultry manure, FYM or vermicompost are recommendable practices for higher tubers productivity, enhanced N, P and K uptake and higher returns. Application of organic manures either alone or in conjunction with inorganic fertilizer improved fertility status of soil over the years. Thus organic manures and biofertilizers should be a part of the agronomic practices for potato cultivation in hills.

\section{Acknowledgement}

The senior author is grateful to the Director, Central Potato Research Institute, Shimla and Head, Central Potato Research Station, Shillong, India for providing the field and lab facilities to carry out the study.

\section{References}

Arora, S. (2008). Balanced nutrition for sustainable crop production. Krishi World (Pulse of Indian Agriculture) pp 1-5.

Asiegbu, J. E. \& Oikeh, S. (1995). Evaluation of chemical composition of manures from different organic wastes and their potential for supply of nutrients to tomato in tropical ultisols. Biological Agric. Horti., 12, 47-60.

Baishya, L. K. (2009). Response of potato varieties to organic and inorganic sources of nutrients. Ph. D. Thesis submitted to Visva-Bharati, West Bengal, India pp 99-102.

Burman, R. R., Kumar, M. \& Nagraj, K. M. (2007). Organic potato production practices and extension strategies. In advancing in organic farming Technology in India. (Edited by Munda, GC, Ghosh PK, Das A, Nagchan SV, Bujarbaruah KM) pp 271-279.

Chadha, S., Rana, S. S., Rameshwar, \& Chaudhary. D. R. (2006). Effect of split doses of N and K and FYM level on the productivity of potato in cold desert region of HP. Potato Journal, 33, 94-96.

Das, P. P., Sarkar, A. \& Zamen. A. (2009). Response of organic and inorganic sources of nutrients on growth and yield of potato in Gangetic alluvial plains of west Bengal. Proc. $96^{\text {th }}$ Indian Science Congress, part-II (Abstract). held on 3-7 $7^{\text {th }}$ January at NEHU, Shillong, Meghalaya.

Ghosh, D. C. \& Malik, G. C. (1999). Fertilizer management in potato under potato-sesame-rice cropping system. Environment and Ecology, 17, 643-645. 
Ghosh, P. K., Saha, R., Gupta, J. J., Ramesh, T., Das, A., Lama, T. D., Munda, G. C., Bordoloi, J. S., Verma, M. R. \& Ngachan, S. V. (2009). Long term effect of pastures on soil quality in acid soil of North-East India. Australian J. Soil Res, 47, 372-379. http://dx.doi.org/10.1071/SR08169

Hedge, D. M. \& Dwivedi. B. S. (1993). Integrated nutrient supply and management as a strategy meet nutrient demand. Fertilizer News, 38, 49-50.

Kumar, R., Khurana, S. C. \& Pandita, M. L. (1992). Effect of seed size, seed rate and fertilizer level on growth and yield of potato Cv. Kufri Badshah. Harayana Agricultural University Journal of Research, 22, 101-105.

Kumar, V., Jaiswal, R. C. \& Singh, A. P. (2001). Effect of biofertilizers on growth and yield of potato. Journal of Indian potato Assoc, 28, 6-7.

Kumar, M., Baishya, L. K., Ghosh, D. C. \& Gupta, V. K. (2011). Yield and quality of potato (Solanum tuberosum) tubers as influenced by nutrient sources under rainfed condition of Meghalaya. Indian Journal of Agronomy, 56(3), 260-266.

Kumar M., Jadav, M. K. \& Trehan, S. P. (2008). Contributing of organic sources to potato nutrition at varying nitrogen levels. Global potato conference, New Delhi. 9-12 Dec, 2008.

Malik G. C. \& Ghosh. D. C. (2002). Effect of fertility level, plant density and variety on growth and productivity of potato. In Potato-Global Research and Development. Vol. - II, pp 866-871.

Manna M. C., Swarup, A. Wanjari, R.H., Singh., Y.V. Ghosh., P.K., Singh, K.N., Tripathi, A.K. \& Saha, M.N. (2006). Soil organic matter in West Bengal inceptisol after 30 years of multiple cropping and fertilization. Soil Science Soc. Am. Journal, 70, 121-129. http://dx.doi.org/10.2136/sssaj2005.0180

Mondal, S. S., Saha, M., Acharya, D., Patra, D. \& Chatterjee, S. (2007). Integrated effect of N and K with or without Sulphur and FYM on potato tuber yield. Storage and soil fertility status. Potato Journal, 34, 97-98.

Nandekar, D. N., Swarka, S. D. \& Naidu, A. K. (2006). Effect of biofertilizers and NPK on the growth and yield of potato in satpura plateau. Potato Journal, 33, 168-169.

Khurana, P. S. M. \& Naik. P. S. (2003). The Potato: an overview. In the Potato Production and Utilization in Sub-tropics (Edited by S. M. Paul Khurana, J. S. Minas and S. K. Pandy) Mehta Publication, New Delhi, 1-14.

Prahara, C. S., Kumar, Dhrub \& Sharma, R. C. (2002). In. Extended summaries of the $2^{\text {nd }}$ international congress on Balancing Food and Environmental security - a continuing challenge, Nov. 26-30, 2002. IARI, New Delhi, pp. 232-33.

Raghav, M. \& Kamal. S. (2008). Organic farming technology for higher and eco-friendly potato production in tarai region of Uttrakhand. Global potato conference, New Delhi. 9-12 Dec, 2008.

Singh, N. P., Ojha, A. P. \& Kumar. V. (1986). Response of potato varieties on various fertility levels. Progresive Horticulture, 18, 114-117.

Singh. K. (2002). Role of biofertilizers in increasing the efficiency of nitrogen to potato crop under northeastern hill conditions. Indian Potato Assoc., 2, 904-907.

Singh, S. N., Singh, B. P., Singh, O. P., Singh, R. \& Singh. R. K. (2007). Effect of nitrogen application in conjuction with bio-inoculant on the growth, yield and quality of potato under indo-gangetic plain region. Potato Journal, 34, 103-104.

Sood, M. C. (2007). Integrated nutrient supply and management for potato production in mid hills of Shimla. Potato Journal, 34, 101-102.

Swaminathan, M. S. (2004). Extending the "Feel Good Factor" to rural and Farming families, Nature, 2004. International Conference on Organic Food. pp. 3-5.

Upadhayay, N. C. \& Singh. J. P. (2003). The Potato (Production and utilization in Sub-Tropics) Edited by SM Paul Khurana, JS. Minhas and SK Pandey. Published by Mehta Publishers, A-16(East), Naraina II, New Delhi-110028, India.

Zaman, A., Sarkar, A., Sarkar, S. \& Devi. W.P. (2011). Effect of organic and inorganic sources of nutrients on productivity, specific gravity and processing quality of potato (Solanum tuberosum). Indian Journal of Agricultural Sciences, 81(12), 1137-42. 
Table 1. Average nutrient content of different organic manures

\begin{tabular}{|l|c|c|c|c|c|c|c|}
\hline Organic Manures & $\begin{array}{c}\mathrm{N} \\
(\%)\end{array}$ & $\begin{array}{c}\mathrm{P} \\
(\%)\end{array}$ & $\begin{array}{c}\mathrm{K} \\
(\%)\end{array}$ & $\begin{array}{c}\mathrm{Fe} \\
(\mathrm{ppm})\end{array}$ & $\begin{array}{c}\mathrm{Cu} \\
(\mathrm{ppm})\end{array}$ & $\begin{array}{c}\mathrm{Zn} \\
(\mathrm{ppm})\end{array}$ & $\begin{array}{c}\mathrm{Mn} \\
(\mathrm{ppm})\end{array}$ \\
\hline FYM & 0.53 & 0.29 & 0.61 & 3520 & 57 & 315 & 281 \\
\hline Vermicompost & 1.20 & 0.65 & 0.80 & 8618 & 61 & 328 & 345 \\
\hline Poultry manure & 1.52 & 0.82 & 0.87 & 1400 & 7 & 90 & 210 \\
\hline
\end{tabular}

Table 2. Effect of nutrient management and biofertilizers on grade wise tuber yield $(\mathrm{t} / \mathrm{ha})$ of potato

\begin{tabular}{|c|c|c|c|c|c|c|c|c|c|}
\hline & \multicolumn{3}{|c|}{2005} & \multicolumn{3}{|c|}{2006} & \multicolumn{3}{|c|}{2007} \\
\hline Nutrient management & $\begin{array}{c}\text { Grade } \\
\text { A }\end{array}$ & $\begin{array}{c}\text { Grade } \\
\text { B }\end{array}$ & $\begin{array}{c}\text { Grade } \\
\text { C }\end{array}$ & $\begin{array}{c}\text { Grade } \\
\text { A }\end{array}$ & $\begin{array}{c}\text { Grade } \\
\text { B }\end{array}$ & $\begin{array}{l}\text { Grade } \\
\text { C }\end{array}$ & $\begin{array}{c}\text { Grade } \\
\text { A }\end{array}$ & $\begin{array}{c}\text { Grade } \\
\text { B }\end{array}$ & $\begin{array}{l}\text { Grade } \\
\text { C }\end{array}$ \\
\hline $\begin{array}{l}\text { Control (No manures and } \\
\text { fertilizers) }\end{array}$ & 1.70 & 5.48 & 3.42 & 1.61 & 4.98 & 3.05 & 1.6 & 4.94 & 3.10 \\
\hline $100 \%$ RDN* through FYM & 3.82 & 8.46 & 3.37 & 4.06 & 9.04 & 3.15 & 4.31 & 9.26 & 3.1 \\
\hline $\begin{array}{l}100 \% \text { RDN through Poultry } \\
\text { manure }\end{array}$ & 4.06 & 8.9 & 3.54 & 4.58 & 9.5 & 2.96 & 4.62 & 9.52 & 2.95 \\
\hline $\begin{array}{l}100 \% \text { RDN through } \\
\text { Vermicompost }\end{array}$ & 3.94 & 8.72 & 3.43 & 4.28 & 9.24 & 3.12 & 4.40 & 9.37 & 3.1 \\
\hline $\begin{array}{l}50 \% \text { RDNPK through } \\
\text { fertilizers } \\
+50 \% \text { RDN through FYM }\end{array}$ & 6.46 & 10.73 & 4.17 & 6.76 & 11.68 & 3.41 & 6.79 & 11.73 & 3.4 \\
\hline $\begin{array}{l}50 \% \text { RDNPK through } \\
\text { fertilizers }+50 \% \text { RDN } \\
\text { through Poultry manure }\end{array}$ & 6.63 & 11.28 & 4.27 & 7.07 & 12.16 & 3.61 & 7.24 & 12.39 & 3.55 \\
\hline $\begin{array}{l}50 \% \text { RDNPK through } \\
\text { fertilizers } \\
+50 \% \text { RDN through } \\
\text { Vermicompost }\end{array}$ & 6.53 & 11.06 & 4.41 & 6.88 & 11.86 & 3.52 & 6.87 & 11.91 & 3.42 \\
\hline $\begin{array}{l}100 \% \text { RDNPK through } \\
\text { fertilizers }\end{array}$ & 6.59 & 10.83 & 4.22 & 6.95 & 12.02 & 3.41 & 7.03 & 12.17 & 3.37 \\
\hline $\operatorname{SEm}( \pm)$ & 0.097 & 0.193 & 0.082 & 0.112 & 0.201 & 0.078 & 0.182 & 0.273 & 0.85 \\
\hline $\mathrm{CD}(P=0.05)$ & 0.294 & 0.581 & 0.245 & 0.336 & 0.607 & 0.235 & 0.509 & 0.765 & 2.54 \\
\hline Biofertilizer & & & & & & & & & \\
\hline Azotobactor & 4.75 & 9.24 & 3.69 & 5.05 & 9.81 & 3.07 & 5.13 & 9.92 & 30.42 \\
\hline $\begin{array}{l}\text { Phosphate solubilising } \\
\text { bacteria (PSB) }\end{array}$ & 4.87 & 9.33 & 3.85 & 5.20 & 9.92 & 3.17 & 5.32 & 10.10 & 32.40 \\
\hline Azotobactor + PSB & 5.28 & 9.73 & 4.11 & 5.57 & 10.45 & 3.6 & 5.63 & 10.46 & 34.63 \\
\hline $\operatorname{SEm}( \pm)$ & 0.071 & 0.085 & 0.069 & 0.065 & 0.105 & 0.062 & 0.101 & 0.118 & 0.74 \\
\hline $\mathrm{C} \mathrm{D}(P=0.05)$ & 0.215 & 0.253 & 0.206 & 0.194 & 0.312 & 0.179 & 0.301 & 0.352 & 2.08 \\
\hline $\mathrm{CV}(\%)$ & 6.5 & 5.9 & 7.0 & 7.7 & 6.3 & 8.5 & 10.4 & 7.5 & 9.3 \\
\hline
\end{tabular}

*RDN (Recommend dose of N) $=120 \mathrm{~kg} \mathrm{~N} / \mathrm{ha}$; RDNPK (Recommend doses of fertilizers) = $120 \mathrm{~kg} \mathrm{~N} / \mathrm{ha}, 120$ $\mathrm{kg} \mathrm{P}_{2} \mathrm{O}_{5} / \mathrm{ha}$ and $60 \mathrm{~kg} \mathrm{~K} \mathrm{~K}_{2} \mathrm{O}$ ha. SEm ( \pm ) standard error of means, CD critical difference, CV coefficient of variation 
Table 3. Effect of nutrient management and biofertilizers on total tuber yield $(\mathrm{t} / \mathrm{ha})$ of potato

\begin{tabular}{|l|c|c|c|c|}
\hline Nutrient management & 2005 & 2006 & 2007 & Pooled \\
\hline Control (No manures and fertilizers) & 10.60 & 9.64 & 9.64 & 9.96 \\
\hline $100 \%$ RDN* through FYM & 15.65 & 16.25 & 16.67 & 16.19 \\
\hline $100 \%$ RDN through Poultry manure & 16.46 & 17.05 & 17.08 & 16.86 \\
\hline $100 \%$ RDN through Vermicompost & 16.09 & 16.64 & 16.88 & 16.54 \\
\hline $\begin{array}{l}50 \% \text { RDNPK through fertilizers } \\
+50 \% \text { RDN through FYM }\end{array}$ & 21.37 & 21.85 & 21.92 & 21.71 \\
\hline $\begin{array}{l}50 \% \text { RDNPK through fertilizers }+50 \% \text { RDN through Poultry manure } \\
\text { 50\% RDNPK through fertilizers }\end{array}$ & 22.18 & 22.85 & 23.17 & 22.73 \\
\hline $50 \%$ RDN through Vermicompost & 22.01 & 22.27 & 22.21 & 22.16 \\
\hline $100 \%$ RDNPK through fertilizers & 21.64 & 22.38 & 22.58 & 22.20 \\
\hline SEm $( \pm)$ & 0.53 & 0.54 & 0.52 & 0.53 \\
\hline C D $(P=0.05)$ & 1.61 & 1.62 & 1.56 & 1.26 \\
\hline Biofertilizer & & & & \\
\hline Azotobactor & 17.69 & 17.93 & 18.09 & 17.90 \\
\hline Phosphate solubilising bacteria (PSB) & 18.05 & 18.29 & 18.66 & 18.33 \\
\hline Azotobactor + PSB & 19.12 & 19.62 & 19.55 & 19.43 \\
\hline SEm $( \pm)$ & 0.27 & 0.29 & 0.30 & 0.20 \\
\hline C D $(P=0.05)$ & 0.80 & 0.88 & 0.89 & 0.59 \\
\hline C V $(\%)$ & 7.70 & 8.10 & 8.30 & \\
\hline
\end{tabular}

*RDN (Recommend dose of N) $=120 \mathrm{~kg} \mathrm{~N} / \mathrm{ha}$; RDNPK (Recommend doses of fertilizers) = $120 \mathrm{~kg} \mathrm{~N} / \mathrm{ha}, 120$ $\mathrm{kg} \mathrm{P}_{2} \mathrm{O}_{5} / \mathrm{ha}$ and $60 \mathrm{~kg} \mathrm{~K} \mathrm{~K}_{2} \mathrm{O}$ ha. $\mathrm{SEm}( \pm)$ standard error of means, CD critical difference, CV coefficient of variation

Table 4. Effect of nutrient management and biofertilizers on nutrient uptake $(\mathrm{kg} / \mathrm{ha})$ by tuber

\begin{tabular}{|c|c|c|c|c|c|c|c|c|c|}
\hline & \multicolumn{3}{|c|}{2005} & \multicolumn{3}{|c|}{2006} & \multicolumn{3}{|c|}{2007} \\
\hline Nutrient management & $\mathrm{N}$ & $\mathrm{P}$ & $\mathrm{K}$ & $\mathrm{N}$ & $\mathrm{P}$ & $\mathrm{K}$ & $\mathrm{N}$ & $\mathrm{P}$ & $\mathrm{K}$ \\
\hline Control (No manures and fertilizers) & 37.58 & 7.75 & 44.95 & 38.49 & 8.94 & 47.74 & 37.77 & 8.59 & 47.45 \\
\hline $100 \%$ RDN* through FYM & 52.77 & 10.54 & 64.02 & 55.42 & 12.75 & 68.21 & 57.93 & 13.29 & 71.33 \\
\hline $100 \%$ RDN through Poultry manure & 55.77 & 11.25 & 67.53 & 57.37 & 13.74 & 72.25 & 60.53 & 14.49 & 73.43 \\
\hline $100 \%$ RDN through Vermicompost & 55.18 & 10.97 & 68.52 & 56.21 & 12.16 & 71.16 & 59.51 & 12.89 & 72.10 \\
\hline $\begin{array}{l}50 \% \text { RDNPK through fertilizers } \\
+50 \% \text { RDN through FYM }\end{array}$ & 65.98 & 15.40 & 91.42 & 71.21 & 16.17 & 91.09 & 71.24 & 18.17 & 95.70 \\
\hline $\begin{array}{l}50 \% \text { RDNPK through fertilizers }+ \\
50 \% \text { RDN through Poultry manure }\end{array}$ & 74.01 & 17.11 & 97.62 & 74.53 & 18.00 & 96.50 & 75.47 & 19.23 & 98.09 \\
\hline $\begin{array}{l}50 \% \text { RDNPK through fertilizers } \\
+50 \% \text { RDN through Vermicompost }\end{array}$ & 72.05 & 16.16 & 96.44 & 73.65 & 17.64 & 95.93 & 74.31 & 19.11 & 97.86 \\
\hline $100 \%$ RDNPK through fertilizers & 72.08 & 16.38 & 95.46 & 72.31 & 17.67 & 95.66 & 72.41 & 18.50 & 96.36 \\
\hline $\operatorname{SEm}( \pm)$ & 0.84 & 0.44 & 1.27 & 1.05 & 0.45 & 0.70 & 1.22 & 0.36 & 1.03 \\
\hline $\mathrm{CD}(P=0.05)$ & 2.25 & 1.75 & 3.86 & 3.15 & 1.33 & 2.14 & 3.42 & 1.01 & 2.89 \\
\hline Biofe & & & & & & & & & \\
\hline Azotobacter & 58.83 & 12.03 & 76.40 & 60.46 & 13.77 & 77.63 & 61.51 & 14.41 & 79.51 \\
\hline Phosphate solubilising bacteria (PSB) & 60.79 & 13.18 & 78.61 & 62.43 & 14.91 & 80.16 & 64.26 & 15.77 & 81.83 \\
\hline Azotobacter + PSB & 62.42 & 14.38 & 79.73 & 63.90 & 15.23 & 81.66 & 65.18 & 16.42 & 83.42 \\
\hline $\operatorname{SEm}(+)$ & 0.52 & 0.28 & 0.57 & 0.44 & 0.31 & 0.65 & 0.75 & 0.29 & 0.73 \\
\hline $\mathrm{CD}(P=0.05)$ & 1.53 & 0.83 & 1.64 & 1.31 & 0.91 & 1.92 & 2.23 & 0.87 & 2.15 \\
\hline C V $(\%)$ & 7.7 & 8.9 & 7.3 & 7.4 & 6.8 & 7.4 & 7.6 & 7.0 & 6.7 \\
\hline
\end{tabular}

$*$ RDN (Recommend dose of N) $=120 \mathrm{~kg} \mathrm{~N} / \mathrm{ha}$; RDN PK (Recommend doses of fertilizers) = $120 \mathrm{~kg} \mathrm{~N} / \mathrm{ha}, 120$ $\mathrm{kg} \mathrm{P}_{2} \mathrm{O}_{5} / \mathrm{ha}$ and $60 \mathrm{~kg} \mathrm{~K} \mathrm{~K}_{2} \mathrm{Oha}$. SEm $( \pm)$ standard error of means, CD critical difference, CV coefficient of variation 
Table 5. Effect of nutrient management and biofertilizers on nutrient uptake $(\mathrm{kg} / \mathrm{ha})$ by haulm

\begin{tabular}{|l|c|c|c|c|c|c|c|c|c|}
\hline & \multicolumn{3}{|c|}{2005} & \multicolumn{3}{|c|}{2006} & \multicolumn{3}{c|}{2007} \\
\hline Nutrient management & $\mathrm{N}$ & $\mathrm{P}$ & $\mathrm{K}$ & $\mathrm{N}$ & $\mathrm{P}$ & $\mathrm{K}$ & $\mathrm{N}$ & $\mathrm{P}$ & $\mathrm{K}$ \\
\hline Control (No manures and fertilizers) & 18.79 & 3.50 & 25.01 & 20.30 & 4.38 & 30.31 & 21.26 & 4.22 & 29.01 \\
\hline $100 \%$ RDN* through FYM & 27.45 & 7.73 & 38.17 & 30.04 & 8.15 & 41.62 & 31.10 & 9.05 & 42.07 \\
\hline 100\% RDN through Poultry manure & 29.21 & 8.63 & 41.75 & 33.66 & 9.87 & 42.13 & 33.02 & 9.97 & 44.11 \\
\hline $100 \%$ RDN through Vermicompost & 28.17 & 8.27 & 39.76 & 32.26 & 9.21 & 41.95 & 32.92 & 9.79 & 43.17 \\
\hline $\begin{array}{l}50 \% \text { RDNPK through fertilizers } \\
+50 \% \text { RDN through FYM }\end{array}$ & 37.64 & 11.72 & 47.44 & 40.38 & 12.74 & 51.75 & 43.13 & 14.71 & 50.53 \\
\hline $\begin{array}{l}\text { 50\% RDNPK through fertilizers + 50\% RDN } \\
\text { through Poultry manure }\end{array}$ & 41.13 & 13.50 & 50.51 & 44.15 & 15.68 & 54.47 & 46.99 & 17.39 & 53.99 \\
\hline $\begin{array}{l}50 \% \text { RDNPK through fertilizers } \\
+50 \% \text { RDN through Vermicompost }\end{array}$ & 38.19 & 12.32 & 48.62 & 42.55 & 14.33 & 52.90 & 43.84 & 15.41 & 52.18 \\
\hline $100 \%$ RDNPK through fertilizers & 41.52 & 14.04 & 51.04 & 44.03 & 15.37 & 54.17 & 45.58 & 16.70 & 53.25 \\
\hline SEm $( \pm)$ & 0.74 & 0.32 & 0.94 & 0.85 & 0.28 & 0.81 & 0.85 & 0.30 & 0.80 \\
\hline C D $(P=0.05)$ & 2.25 & 0.98 & 2.86 & 2.60 & 0.83 & 2.48 & 2.37 & 0.85 & 2.38 \\
\hline Biofertilizer & & & & & & & & & \\
\hline Azotobactor & 31.39 & 9.36 & 40.78 & 34.31 & 10.01 & 44.11 & 35.39 & 11.00 & 44.25 \\
\hline Phosphate solubilising bacteria (PSB) & 32.49 & 9.98 & 42.76 & 36.00 & 11.55 & 46.28 & 37.02 & 12.46 & 46.44 \\
\hline Azotobactor + PSB & 34.40 & 10.51 & 44.66 & 37.00 & 12.03 & 47.48 & 39.31 & 13.00 & 47.43 \\
\hline SEm $( \pm)$ & 0.51 & 0.21 & 0.63 & 0.54 & 0.19 & 0.71 & 0.52 & 0.21 & 0.43 \\
\hline C D $(P=0.05)$ & 1.47 & 0.62 & 1.83 & 1.55 & 0.54 & 2.04 & 1.53 & 0.62 & 1.27 \\
\hline C V $(\%)$ & 6.1 & 7.9 & 4.7 & 8.7 & 7.5 & 5.6 & 6.8 & 7.5 & 6.3 \\
\hline
\end{tabular}

*RDN (Recommend dose of N) $=120 \mathrm{~kg} \mathrm{~N} / \mathrm{ha}$; RDNPK (Recommend doses of fertilizers) $=120 \mathrm{~kg} \mathrm{~N} / \mathrm{ha}, 120$ $\mathrm{kg} \mathrm{P}_{2} \mathrm{O}_{5} / \mathrm{ha}$ and $60 \mathrm{~kg} \mathrm{~K} 2 \mathrm{O} / \mathrm{ha}$. SEm $( \pm)$ standard error of means, CD critical difference, ${ }_{2} \mathrm{CV}$ coefficient of variation

Table 6. Effect of nutrient management and biofertilizers carbon pool of the soil after three years of potato cultivation

\begin{tabular}{|l|c|c|c|}
\hline Nutrient management & ${ }^{\wedge} \mathrm{TOC}(\mathrm{g} / \mathrm{kg})$ & ${ }^{* *} \mathrm{SMBC}(\mathrm{mg} / \mathrm{kg})$ & $\mathrm{SMBC} / \mathrm{TOC}(\mathrm{mg} / \mathrm{g})$ \\
\hline Control (No manures and fertilizers) & 9.13 & 121.5 & 13.31 \\
\hline $100 \%$ RDN* through FYM & 14.43 & 196.4 & 13.61 \\
\hline $100 \%$ RDN through Poultry manure & 14.33 & 193.8 & 13.52 \\
\hline $100 \%$ RDN through Vermicompost & 14.23 & 197.0 & 13.84 \\
\hline $\begin{array}{l}50 \% \text { RDNPK through fertilizers } \\
+50 \% \text { RDN through FYM }\end{array}$ & 13.73 & 173.2 & 12.61 \\
\hline $\begin{array}{l}50 \% \text { RDNPK through fertilizers + 50\% RDN } \\
\text { through Poultry manure }\end{array}$ & 13.63 & 171.4 & 12.58 \\
\hline $\begin{array}{l}50 \% \text { RDNPK through fertilizers } \\
+50 \% \text { RDN through Vermicompost }\end{array}$ & 13.63 & 175.4 & 12.87 \\
\hline $100 \%$ RDNPK through fertilizers & 13.13 & 143.9 & 10.96 \\
\hline SEm $(+)$ & 0.13 & 3.71 & 0.55 \\
\hline C D $(P=0.05)$ & 0.37 & 10.75 & 1.60 \\
\hline Biofertilizer & & & 13.02 \\
\hline Azotobactor & 13.09 & 170.4 & 12.98 \\
\hline Phosphate solubilising bacteria (PSB) & 13.25 & 172.0 & 12.87 \\
\hline Azotobactor + PSB & 13.51 & 173.9 & 0.36 \\
\hline SEm $( \pm)$ & 0.18 & 2.32 & $\mathrm{NS}$ \\
\hline C D $(P=0.05)$ & $\mathrm{NS}$ & $\mathrm{NS}$ & 11.79 \\
\hline Initial value & 12.30 & 145.0 & $120 \mathrm{~kg} \mathrm{N/n}$ \\
\hline
\end{tabular}

$* \mathrm{RDN}($ Recommend dose of N) $=120 \mathrm{~kg} \mathrm{~N} / \mathrm{ha}$; RDNPK (Recommend doses of fertilizers) $=120 \mathrm{~kg} \mathrm{~N} / \mathrm{ha}, 120$ $\mathrm{kg} \mathrm{P}_{2} \mathrm{O}_{5} /$ ha and $60 \mathrm{~kg} \mathrm{~K}_{2} \mathrm{O} / \mathrm{ha}$.TOC=Total organic Carbon; **SMBC= Soil Microbial Biomass Carbon. SEm ( \pm ) standard error of means, $\mathrm{CD}$ critical difference, $\mathrm{CV}$ coefficient of variation 
Table 7. Effect of nutrient management practices on available soil nutrient status $(\mathrm{kg} / \mathrm{ha})$ of the experimental soil

\begin{tabular}{|l|c|c|c|c|c|c|c|c|c|}
\hline Nutrient management & \multicolumn{3}{|c|}{ After $1^{\text {st }}$ crop $(2005)$} & \multicolumn{3}{c|}{ After $2^{\text {nd }}$ crop (2006) } & \multicolumn{3}{|c|}{ After $3^{\text {rd }}$ crop (2007) } \\
\hline & $\mathrm{N}$ & $\mathrm{P}$ & $\mathrm{K}$ & $\mathrm{N}$ & $\mathrm{P}$ & $\mathrm{K}$ & $\mathrm{N}$ & $\mathrm{P}$ & $\mathrm{K}$ \\
\hline Control (No manures and fertilizers) & 177.7 & 13.66 & 193.7 & 174.2 & 12.81 & 192.4 & 172.0 & 11.23 & 190.2 \\
\hline 100\% RDN* through FYM & 217.3 & 15.63 & 221.2 & 233.3 & 17.44 & 246.8 & 244.8 & 21.91 & 263.6 \\
\hline 100\% RDN through Poultry manure & 219.8 & 17.05 & 225.7 & 235.5 & 18.05 & 249.8 & 246.7 & 22.70 & 264.7 \\
\hline 100\% RDN through Vermicompost & 216.8 & 15.35 & 221.7 & 233.5 & 16.50 & 245.3 & 244.0 & 21.6 & 262.0 \\
\hline $\begin{array}{l}50 \% \text { RDNPK through fertilizers } \\
+50 \% \text { RDN through FYM }\end{array}$ & 222.5 & 18.15 & 232.7 & 242.4 & 21.36 & 253.6 & 252.0 & 24.85 & 269.2 \\
\hline $\begin{array}{l}50 \% \text { RDNPK through fertilizers + } \\
50 \% \text { RDN through Poultry manure }\end{array}$ & 224.0 & 19.03 & 235.6 & 245.1 & 22.52 & 256.4 & 253.3 & 26.37 & 271.1 \\
\hline $\begin{array}{l}50 \% \text { RDNPK through fertilizers } \\
+50 \% \text { RDN through Vermicompost }\end{array}$ & 221.5 & 17.88 & 232.4 & 242.1 & 20.27 & 251.6 & 251.6 & 24.01 & 268.8 \\
\hline 100\% RDNPK through fertilizers & 210.2 & 15.01 & 216.5 & 226.2 & 16.16 & 233.2 & 236.5 & 21.63 & 252.8 \\
\hline SEm $( \pm)$ & 3.6 & 0.76 & 4.6 & 4.1 & 0.69 & 6.1 & 3.7 & 0.51 & 5.1 \\
\hline C D $(P=0.05)$ & 10.5 & 2.20 & 13.9 & 12.2 & 2.05 & 17.5 & 10.8 & 1.51 & 14.2 \\
\hline Biofertilizer & & & & & & & & & \\
\hline Azotobactor & 212.0 & 16.58 & 223.2 & 228.1 & 16.81 & 240.6 & 237.0 & 21.32 & 259.1 \\
\hline Phosphate solubilising bacteria (PSB) & 212.9 & 16.91 & 224.0 & 229.0 & 17.27 & 241.3 & 237.5 & 21.66 & 260.7 \\
\hline Azotobactor + PSB & 214.0 & 17.00 & 225.0 & 230.4 & 17.40 & 243.0 & 238.3 & 22.10 & 261.3 \\
\hline SEm $( \pm)$ & 1.8 & 0.26 & 2.2 & 2.0 & 0.28 & 2.3 & 1.8 & 0.30 & 2.1 \\
\hline C D $(P=0.05)$ & $\mathrm{NS}$ & $\mathrm{NS}$ & $\mathrm{NS}$ & $\mathrm{NS}$ & $\mathrm{NS}$ & $\mathrm{NS}$ & $\mathrm{NS}$ & $\mathrm{NS}$ & $\mathrm{NS}$ \\
\hline Initial value & 179.5 & 13.35 & 195.1 & & & & & & \\
\hline
\end{tabular}

*RDN (Recommend dose of N) $=120 \mathrm{~kg} \mathrm{~N} / \mathrm{ha}$; RDNPK (Recommend doses of fertilizers) $=120 \mathrm{~kg} \mathrm{~N} / \mathrm{ha}, 120$ $\mathrm{kg} \mathrm{P}_{2} \mathrm{O}_{5} / \mathrm{ha}$ and $60 \mathrm{~kg} \mathrm{~K} \mathrm{~K}_{2} \mathrm{O} / \mathrm{ha}$. SEm $( \pm)$ standard error of means, CD critical difference, CV coefficient of variation

Table 8. Effect of nutrient management and biofertilizers on economics of potato production (Mean of 3 years)

\begin{tabular}{|c|c|c|c|c|}
\hline Nutrient management & $\begin{array}{c}\text { Cost of cultivation } \\
(\$ / \text { ha })\end{array}$ & $\begin{array}{l}\text { Gross return } \\
(\$ / \mathrm{ha})\end{array}$ & $\begin{array}{l}\text { Net return } \\
(\$ / \text { ha })\end{array}$ & $\begin{array}{l}\text { Net Return } \\
\text { \$ Investec }\end{array}$ \\
\hline Control (No manures and fertilizers) & 706.70 & 1236.67 & 529.97 & 1.75 \\
\hline $100 \%$ RDN* through FYM & 820.52 & 1612.57 & 792.05 & 1.97 \\
\hline $100 \%$ RDN through Poultry manure & 867.50 & 1673.67 & 806.17 & 1.93 \\
\hline $100 \%$ RDN through Vermicompost & 939.70 & 1652.90 & 713.20 & 1.76 \\
\hline $\begin{array}{l}50 \% \text { RD through fertilizers }+50 \% \text { RDN } \\
\text { through FYM }\end{array}$ & 816.58 & 2169.23 & 1352.65 & 2.66 \\
\hline $\begin{array}{l}50 \% \text { RD through fertilizers }+50 \% \text { RDN } \\
\text { through Poultry manure }\end{array}$ & 843.02 & 2261.23 & 1418.21 & 2.68 \\
\hline $\begin{array}{l}50 \% \text { RD through fertilizers }+50 \% \text { RDN } \\
\text { through Vermicompost }\end{array}$ & 880.16 & 2229.03 & 1348.87 & 2.53 \\
\hline $100 \% \mathrm{RD}$ through fertilizers & 812.52 & 2219.87 & 1407.35 & 2.73 \\
\hline \multicolumn{5}{|l|}{ Biofertilizer } \\
\hline Azotobactor & 913.54 & 1812.77 & 899.23 & 1.98 \\
\hline Phosphate solubilising bacteria (PSB) & 912.78 & 1858.87 & 946.09 & 2.04 \\
\hline Azotobactor + PSB & 913.28 & 1969.87 & 1056.59 & 2.16 \\
\hline
\end{tabular}

$*$ RDN $($ Recommend dose of N) $=120 \mathrm{~kg} \mathrm{~N} / \mathrm{ha}$; RDF (Recommend doses of fertilizers) $=120 \mathrm{~kg} \mathrm{~N} / \mathrm{ha}, 120 \mathrm{~kg}$ P2O5/ha and 60 kg K2O/ha respectively. Potato seed @ \$160/- per ton, Urea @ \$ 0.11/- per kg, SSP @ \$ 0.09/perkg, MOP@ @ 0.1/- per kg, Cow dung@ @ 5.5/- per ton, Poultry manure@ @.20/- per ton, vermicompost (own farm production)@ @30/-per ton, Biofertilizers@ @ 5/-perkg, Labour charges@ @1.2/- per man-day and price of potato tubers $@ \$ 100 /$-per ton. 


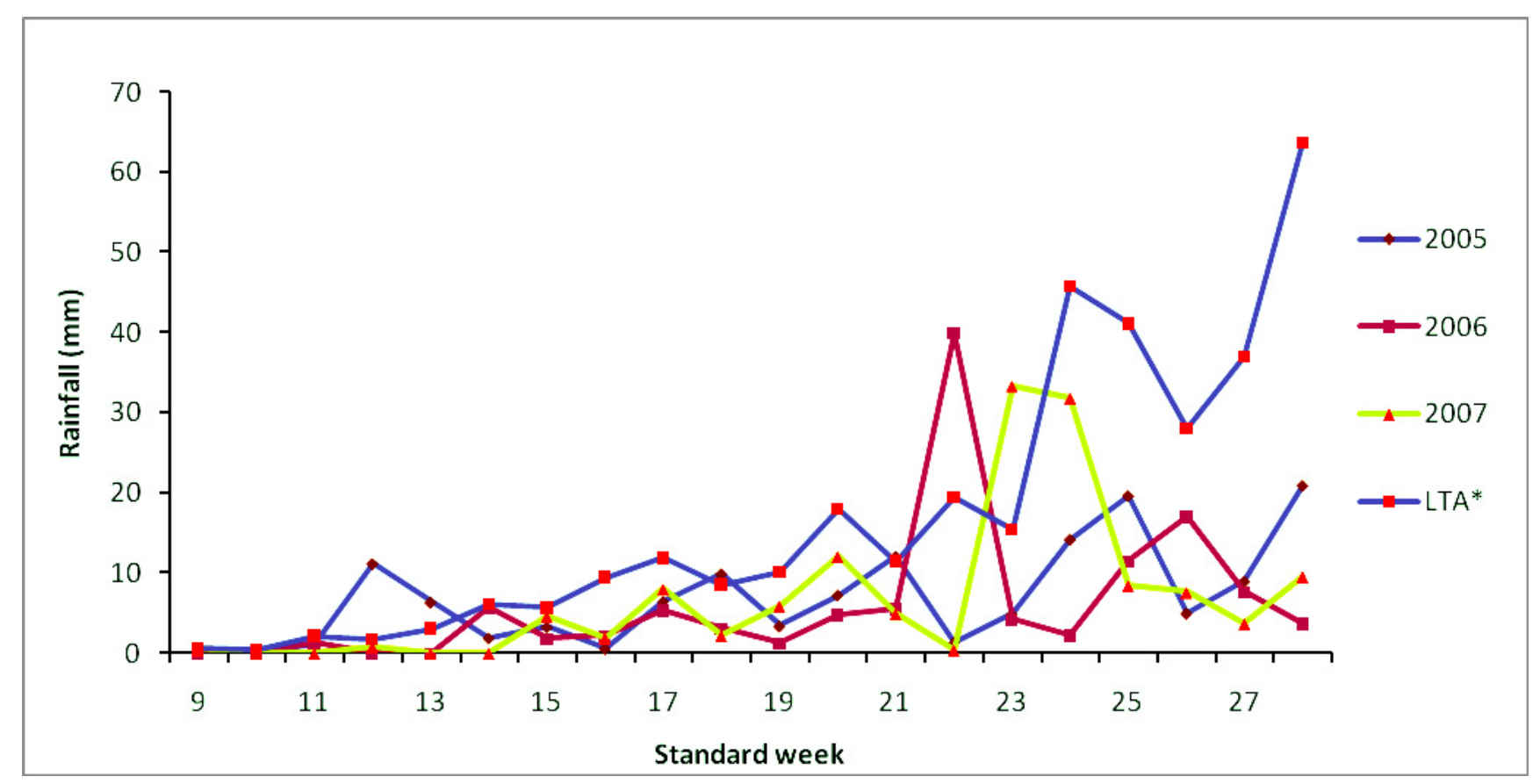

Figure 1. Weekly rainfall received during the cropping season

*LTA - Long term average 